\title{
COVID-19 Infection Associated With Encephalitis in an Adolescent
} Sejal M. Bhavsar, MD, Saranga Agarwal, MD, Rachel Lewis, MD, Avani Ganta, MBBS, Yelena S. Roshchina, MD,
Katharine N. Clouser, MD, Aryeh Z. Baer, MD, Felicia Gliksman, MD, and Julia A. Piwoz, MD

\section{Correspondence}

Dr. Bhavsar

sejal.bhavsar@

hackensackmeridian.org

Although adults with coronavirus disease 2019 (COVID-19) who require admission to the hospital have often required critical care, infants and children with COVID-19 have generally demonstrated milder disease severity, fewer complications, and overall a much lower case fatality rate. Neurologic manifestations have been reported with COVID-19 in adult patients including acute cerebrovascular disease, ischemic and hemorrhagic strokes, skeletal muscle injury, and rare cases of encephalopathy. We report here an adolescent patient with acute encephalitis associated with COVID-19.

\section{Case}

A 16-year-old previously healthy boy presented to the emergency department (ED) at the Joseph M. Sanzari Children's Hospital at Hackensack University Medical Center with fever up to $101^{\circ} \mathrm{F}$ for 9 days, followed by generalized weakness and somnolence for 2 days. He had pharyngitis and intermittent headaches, which prompted evaluation at a local ED 4 days before admission. Rapid tests for influenza and streptococcal pharyngitis were negative. He was prescribed amoxicillin, and, given the ongoing coronavirus disease 2019 (COVID-19) pandemic, he was instructed to self-isolate at home. Two days later, he developed emesis, severe malaise, progressive somnolence with confusion, and incoherent speech. He was not able to ambulate without assistance, which prompted re-evaluation in our ED.

In the ED, he was afebrile, normotensive, and had an arterial oxygen saturation of $98 \%$ on room air. On neurologic examination, he was difficult to arouse, confused, speaking incoherently, and following commands inconsistently. No papilledema was noted, and his cranial nerve examination was normal. Motor examination was significant for mild to moderate generalized weakness without any focal findings. His deep tendon reflexes were normal, with negative Babinski bilaterally. He was noted to have frequent episodes of eye rolling, lip smacking, and insuppressible left facial and hand twitching for few seconds, which were treated as clinical seizures with $2 \mathrm{mg}$ of lorazepam. The movements recurred soon after, which resolved after receiving $1 \mathrm{~g}$ of levetiracetam. He had a normal cardiopulmonary examination. Abdominal examination was notable for suprapubic tenderness. There was no rash. CT of his head without contrast was normal. A CT scan of his abdomen and pelvis with IV contrast showed bilateral dependent patchy lower lung ground-glass opacities. Chest radiograph had low lung volumes with possible left lower lobe infiltrate. Complete blood count, C-reactive protein, and erythrocyte sedimentation rate obtained secondary to suspicion for infection were normal. A total creatine kinase value was obtained because of his complaint of weakness, which was found to be elevated to $1200 \mathrm{U} / \mathrm{L}$. He had hyponatremia (124 mmol/L) with a serum osmolality of 263 $\mathrm{mOsm} / \mathrm{kg}$. A urine osmolality of $900 \mathrm{mOsm} / \mathrm{kg}$ was suggestive of the diagnosis of syndrome of inappropriate antidiuretic hormone (table 1). Urine drug screen was negative. Respiratory pathogen panel by PCR was negative for common respiratory viruses and atypical bacterial pathogens (table 2).
MORE ONLINE

\section{COVID-19 Resources}

For the latest articles, invited commentaries, and blogs from physicians around the world NPub.org/COVID19

Department of Pediatrics (SMB, SA, RL, YSR, KNC, AZB, FG, JAP), Joseph M. Sanzari Children's Hospital at Hackensack University Medical Center and Hackensack Meridian School of Medicine; and Department of Pediatrics (AG), Rutgers New Jersey Medical School, Newark, NJ.

Funding information and disclosures are provided at the end of the article. Full disclosure form information provided by the authors is available with the full text of this article at Neurology.org/cp. 
Table 1 Laboratory Results

\begin{tabular}{|c|c|}
\hline WBC & 7,500 cells $/ \mathrm{mcL}$ \\
\hline Hemoglobin & $13.8 \mathrm{~g} / \mathrm{dL}$ \\
\hline Platelets & 233,000 cells $/ \mathrm{mcL}$ \\
\hline Neutrophil, \% & 71 \\
\hline Lymphocyte, \% & 15 \\
\hline Monocyte, \% & 11 \\
\hline Eosinophil, \% & 3 \\
\hline Sodium & $124 \mathrm{mmol} / \mathrm{L}$ \\
\hline Potassium & $4 \mathrm{mmol} / \mathrm{L}$ \\
\hline Chloride & $94 \mathrm{mmol} / \mathrm{L}$ \\
\hline $\mathrm{CO}_{2}$ & $21 \mathrm{mmol} / \mathrm{L}$ \\
\hline BUN & 17 mg/dL \\
\hline Creatinine & $0.7 \mathrm{mg} / \mathrm{dL}$ \\
\hline Glucose & 109 mg/dL \\
\hline Calcium & $9 \mathrm{mg} / \mathrm{dL}$ \\
\hline Total protein & $7.5 \mathrm{mg} / \mathrm{dL}$ \\
\hline Albumin & $4.3 \mathrm{mg} / \mathrm{dL}$ \\
\hline Total bilirubin & $0.7 \mathrm{mg} / \mathrm{dL}$ \\
\hline AST & $29 \mathrm{U} / \mathrm{L}$ \\
\hline ALT & $26 \mathrm{U} / \mathrm{L}$ \\
\hline CPK & $1210 \mathrm{U} / \mathrm{L}$ \\
\hline TSH & $2.83 \mathrm{ulU} / \mathrm{mL}$ \\
\hline CRP & $0.1 \mathrm{mg} / \mathrm{dL}$ \\
\hline ESR & $9 \mathrm{~mm} / \mathrm{h}$ \\
\hline Procalcitonin & $0.05 \mathrm{ng} / \mathrm{mL}$ \\
\hline Serum, Osm & $263 \mathrm{mOsm} / \mathrm{kg}$ \\
\hline Urine sodium & $22 \mathrm{mmol} / \mathrm{L}$ \\
\hline Urine, Osm & 900 mOsm/kg \\
\hline
\end{tabular}

Abbreviations: $\mathrm{ALT}=$ alanine aminotransferase; $\mathrm{AST}=$ aspartate aminotransferase; $\mathrm{CPK}=$ creatine phosphokinase; $\mathrm{CRP}=\mathrm{C}$-reactive protein; $\mathrm{ESR}=$ erythrocyte sedimentation rate; $\mathrm{TSH}=$ thyroid stimulating hormone; $\mathrm{WBC}=$ white blood cells.

Due to concern for meningoencephalitis, a lumbar puncture was performed. CSF was clear and had 122 white blood cells/ $\mu \mathrm{L}$ with mononuclear cells predominance. There were 239 red blood cells/mcL, protein was $173 \mathrm{mg} / \mathrm{dL}$, and glucose was $35 \mathrm{mg} / \mathrm{dL}$ (serum glucose $109 \mathrm{mg} / \mathrm{dL}$ ). The Gram stain of his CSF showed no cells or organisms. A meningoencephalitis PCR panel (Biofire ME Film Array) was negative for common viral and bacterial pathogens (table 3 ).

The patient was started on vancomycin and ceftriaxone and was admitted to the pediatric intensive care unit for neurocritical monitoring for acute encephalitis and correction of
Table 2 Respiratory Pathogen Panel by PCR (negative)

\begin{tabular}{ll}
\hline Respiratory pathogen panel & \\
\hline Adenovirus & Not detected \\
\hline Human metapneumovirus & Not detected \\
\hline Human coronaviruses & Not detected \\
\hline Respiratory syncytial virus & Not detected \\
\hline Rhinovirus/enterovirus & Not detected \\
\hline Influenza A or B & Not detected \\
\hline Parainfluenza virus types 1-4 & Not detected \\
\hline Bordetella pertussis & Not detected \\
\hline Mycoplasma pneumoniae & Not detected \\
\hline Chlamydophilia pneumoniae & Not detected
\end{tabular}

hyponatremia. After admission, he became hypothermic with temperatures as low as $91.1^{\circ} \mathrm{F}$ rectally, which slowly improved to normal with external warming measures. $\mathrm{He}$ had bradycardia, with rates ranging between $50-58$ beats per minute, but his perfusion remained normal and he was normotensive. He continued to be lethargic, oriented to name only, and inconsistently followed commands and answered questions. Cranial nerve examination was normal, and he displayed generalized weakness with no focal motor or sensory deficits. Supplemental oxygen via nasal cannula was required briefly in concurrence with alteration of mental status, hypoventilation, and difficulty handling oral secretions. Hyponatremia was initially treated with fluid restriction and hypertonic saline. He was placed on video EEG, which was consistent with encephalopathy, showing slow background without epileptiform discharges or seizures. Further investigation for etiology of encephalitis was performed on serum including negative testing for autoimmune encephalopathy antibody panel. Syphilis and human immunodeficiency virus antibodies were nonreactive. Interferon gamma release assay, Lyme enzyme linked immunosorbent assay, and serum Epstein-Barr virus and cytomegalovirus PCRs were negative. Severe acute respiratory syndrome coronavirus 2 (SARS-CoV-2) testing by in-house RT-PCR from his nasopharynx obtained in the ED resulted as positive. His CSF was experimentally tested for SARS-CoV-2, which was not detected. Antibiotics were discontinued once blood and CSF cultures were negative for 48 hours. Compassionate use of remdesivir for a 10-day course was initiated. The patient's neurologic symptoms started to improve by hospital day 4 , and he was transferred to a lower level of care. During his stay, he continued to have moderate hyponatremia with serum sodium level between 129 and $133 \mathrm{mmol} / \mathrm{L}$, which improved with oral sodium chloride supplements. His mental status remained altered, with inconsistent awareness of time and place, despite normalization of his laboratory test results. One week into admission, he developed pain to palpation in his right 
Table 3 Cerebrospinal Fluid Analysis

\begin{tabular}{|c|c|}
\hline CSF WBC & 122 cells $/ \mathrm{mcL}$ \\
\hline CSF neutrophil, \% & 2 \\
\hline CSF lymph, \% & 74 \\
\hline CSF reactive lymph, \% & 7 \\
\hline CSF monocyte, $\%$ & 11 \\
\hline CSF red blood cells & 239 cells $/ \mathrm{mcL}$ \\
\hline CSF protein & $173 \mathrm{mg} / \mathrm{dL}$ \\
\hline CSF glucose & $35 \mathrm{mg} / \mathrm{dL}$ \\
\hline \multicolumn{2}{|c|}{ CSF meningoencephalitis PCR panel: } \\
\hline Herpes simplex virus 1 and 2 & Not detected \\
\hline Varicella zoster virus & Not detected \\
\hline Enterovirus & Not detected \\
\hline Human herpesvirus 6 & Not detected \\
\hline Cytomegalovirus & Not detected \\
\hline Human parechovirus & Not detected \\
\hline Streptococcus pneumoniae & Not detected \\
\hline Neisseria meningitidis & Not detected \\
\hline Haemophilus influenzae & Not detected \\
\hline Streptococcus agalactie & Not detected \\
\hline Listeria monocytogenes & Not detected \\
\hline Escherichia coli $\mathrm{K} 1$ & Not detected \\
\hline
\end{tabular}

gastrocnemius. A venous Doppler confirmed an infrapopliteal deep venous thrombosis, and he was started on Lovenox, which prolonged his hospital stay. He was discharged home on day 15 with improved mental status and condition, with outpatient therapies arranged.

\section{Discussion}

Previously healthy children have rarely been reported to have severe manifestations with COVID-19. ${ }^{1,2}$ Our report illustrates an adolescent patient with severe infection with neurologic involvement. Neurologic manifestations have been reported in adult patients with COVID-19 including rare cases of encephalopathy. ${ }^{3-5}$ However, true encephalitis with evidence of CNS inflammation in CSF analysis has not yet been reported. There are reports of human coronaviruses associated with neurologic manifestations. ${ }^{6}$ There has been a single report of human coronavirus associated with encephalitis in an 11-month-old boy with severe combined immunodeficiency, which was diagnosed by a postmortem brain biopsy. ${ }^{7}$ Acute disseminated encephalomyelitis has also been associated with human coronaviruses, including in a 15-yearold boy who presented with irritability, focal neurologic findings (right-hand weakness, left-hand dysmetria, bilateral leg numbness, and difficulty walking), and had brain and spine MRI showing multifocal lesions. ${ }^{8}$ Brain MRI can be useful in differentiating these conditions. Our report is limited in that a brain MRI was not performed to limit SARS-CoV-2 exposure within the hospital. In light of his normal CT findings, nonfocal neurologic examination and improving neurologic examination, brain MRI was deferred. If he did decompensate, then brain MRI would have been performed. Although our patient did not present typically with respiratory symptoms, his chest imaging was consistent with COVID-19 with the findings of bilateral ground-glass opacities. He also later developed deep vein thrombosis, which coincides with the reports of increased incidence of thrombotic complications in critically ill intensive care unit patients with COVID-19. ${ }^{9}$

As our patient illustrates, encephalitis may be associated with COVID-19. Patients presenting with symptoms compatible with COVID-19 and encephalitis should be tested for SARS$\mathrm{CoV}-2$ in addition to the usual pathogens associated with neurologic infections.

\section{Study Funding}

No targeted funding reported.

\section{Disclosure}

The authors report no disclosures relevant to the manuscript. Full disclosure form information provided by the authors is available with the full text of this article at Neurology.org/cp.

\section{Publication History}

Received by Neurology: Clinical Practice April 30, 2020. Accepted in final form June 25, 2020.

Appendix Authors

\begin{tabular}{|c|c|c|}
\hline Name & Location & Contribution \\
\hline $\begin{array}{l}\text { Sejal M. } \\
\text { Bhavsar, } \\
\text { MD }\end{array}$ & $\begin{array}{l}\text { Joseph M. Sanzari Children's } \\
\text { Hospital at Hackensack } \\
\text { University Medical Center }\end{array}$ & $\begin{array}{l}\text { Drafted the } \\
\text { original manuscript } \\
\text { and revision of the } \\
\text { manuscript }\end{array}$ \\
\hline $\begin{array}{l}\text { Saranga } \\
\text { Agarwal, } \\
\text { MD }\end{array}$ & $\begin{array}{l}\text { Joseph M. Sanzari Children's } \\
\text { Hospital at Hackensack } \\
\text { University Medical Center }\end{array}$ & $\begin{array}{l}\text { Drafted the original } \\
\text { manuscript } \\
\text { and revision of the } \\
\text { manuscript }\end{array}$ \\
\hline $\begin{array}{l}\text { Rachel } \\
\text { Lewis, MD }\end{array}$ & $\begin{array}{l}\text { Joseph M. Sanzari } \\
\text { Children's Hospital at } \\
\text { Hackensack University } \\
\text { Medical Center }\end{array}$ & $\begin{array}{l}\text { Reviewed and revised } \\
\text { the manuscript }\end{array}$ \\
\hline $\begin{array}{l}\text { Avani } \\
\text { Ganta, } \\
\text { MBBS }\end{array}$ & $\begin{array}{l}\text { Rutger's New Jersey Medical } \\
\text { School }\end{array}$ & $\begin{array}{l}\text { Reviewed and revised } \\
\text { the manuscript }\end{array}$ \\
\hline $\begin{array}{l}\text { Yelena } \\
\text { Roshchina, } \\
\text { MD }\end{array}$ & $\begin{array}{l}\text { Joseph M. Sanzari Children's } \\
\text { Hospital at Hackensack } \\
\text { University Medical Center }\end{array}$ & $\begin{array}{l}\text { Reviewed and revised } \\
\text { the manuscript }\end{array}$ \\
\hline $\begin{array}{l}\text { Katharine } \\
\text { Clouser, } \\
\text { MD }\end{array}$ & $\begin{array}{l}\text { Joseph M. Sanzari } \\
\text { Children's Hospital at } \\
\text { Hackensack University } \\
\text { Medical Center }\end{array}$ & $\begin{array}{l}\text { Reviewed and revised } \\
\text { the manuscript }\end{array}$ \\
\hline
\end{tabular}


Appendix (continued)

\begin{tabular}{lll}
\hline Name & Location & Contribution \\
\hline $\begin{array}{l}\text { Aryeh Baer, } \\
\text { MD }\end{array}$ & $\begin{array}{l}\text { Joseph M. Sanzari Children's } \\
\text { Hospital at Hackensack } \\
\text { University Medical Center }\end{array}$ & $\begin{array}{l}\text { Drafted the } \\
\text { original manuscript } \\
\text { and reviewed the } \\
\text { manuscript }\end{array}$ \\
\hline $\begin{array}{l}\text { Felicia } \\
\text { Gliksman, } \\
\text { MD }\end{array}$ & $\begin{array}{l}\text { Joseph M. Sanzari } \\
\text { Children's Hospital } \\
\text { at Hackensack } \\
\text { University Medical } \\
\text { Center }\end{array}$ & $\begin{array}{l}\text { Reviewed and revised } \\
\text { the manuscript }\end{array}$ \\
\hline $\begin{array}{l}\text { Julia Piwoz, } \\
\text { MD }\end{array}$ & $\begin{array}{l}\text { Joseph M. Sanzari } \\
\text { Children's Hospital at } \\
\text { Hackensack University } \\
\text { Medical Center }\end{array}$ & $\begin{array}{l}\text { Reviewed and revised } \\
\text { the manuscript }\end{array}$ \\
\hline
\end{tabular}

\section{References}

1. Dong Y, Mo X, Hu Y, et al. Epidemiological characteristics of 2143 pediatric patients with 2019 coronavirus disease in China. Pediatrics 2020. doi: 10.1542/peds.2020-0702

2. Severe outcomes among patients with coronavirus disease 2019 (COVID-19) - United States, February 12-March 16, 2020. MMWR Morb Mortal Wkly Rep 2020;69:343-346.

3. Mao L, Jin H, Wang M, et al. Neurologic manifestations of hospitalized patients with coronavirus disease 2019 in Wuhan, China. JAMA Neurol 2020;77:1-9.

4. Helms J, Kremer S, Merdji H, et al. Neurologic features in severe SARS-CoV2 infection. NEJM 2020;382:2268-2270.

5. Filatov A, Sharma P, Hindi F, et al. Neurological complications of coronavirus disease (COVID-19): encephalopathy. Cureus 2020;12:e7352.

6. Desforges M, Le Coupanec A, Dubeau P, et al. Human coronaviruses and other respiratory viruses: underestimated opportunistic pathogens of the central nervous system? Viruses 2019;12:14.

7. Morfopoulou S, Brown JR, Davies EG, et al. Human coronavirus OC43 associated with fatal encephalitis. N Engl J Med 2016;375:497-498.

8. Yeh EA, Collins A, Cohen ME, Duffner PK, Faden H. Detection of coronavirus in the central nervous system of a child with acute disseminated encephalomyelitis. Pediatrics 2004;113:e73-e76.

9. Klok FA, Kruip MJHA, van der Meer NJM, et al. Incidence of thrombotic complications in critically ill ICU patients with COVID-19. Thromb Res 2020;191:145-147. 


\section{Neurology ${ }^{\circ}$ Clinical Practice}

COVID-19 Infection Associated With Encephalitis in an Adolescent

Sejal M. Bhavsar, Saranga Agarwal, Rachel Lewis, et al.

Neurol Clin Pract 2021;11;e189-e192 Published Online before print July 28, 2020

DOI 10.1212/CPJ.0000000000000911

This information is current as of July 28, 2020

Updated Information \&
Services

References

Subspecialty Collections

Permissions \& Licensing

Reprints including high resolution figures, can be found at:

http://cp.neurology.org/content/11/2/e189.full.html

This article cites 9 articles, 0 of which you can access for free at: http://cp.neurology.org/content/11/2/e189.full.html\#\#ref-list-1

This article, along with others on similar topics, appears in the following collection(s):

COVID-19

http://cp.neurology.org//cgi/collection/covid_19

Encephalitis

http://cp.neurology.org//cgi/collection/encephalitis

Viral infections

http://cp.neurology.org//cgi/collection/viral_infections

Information about reproducing this article in parts (figures,tables) or in its entirety can be found online at:

http://cp.neurology.org/misc/about.xhtml\#permissions

Information about ordering reprints can be found online:

http://cp.neurology.org/misc/addir.xhtml\#reprintsus

Neurol Clin Pract is an official journal of the American Academy of Neurology. Published continuously since 2011, it is now a bimonthly with 6 issues per year. Copyright $\odot 2020$ American Academy of Neurology. All rights reserved. Print ISSN: 2163-0402. Online ISSN: 2163-0933.

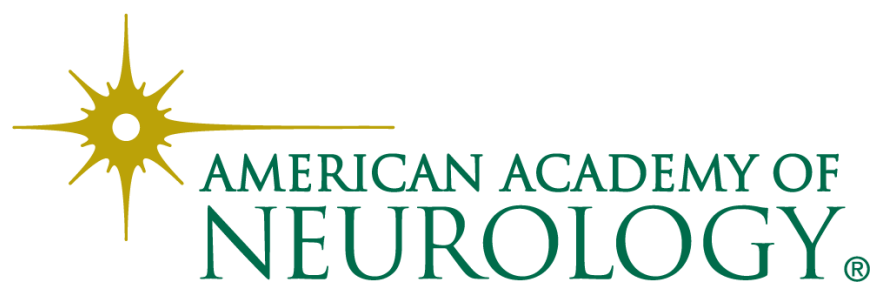

